\title{
IMPACTS OF RISING ANIMAL FOOD PRICES ON DEMAND AND POVERTY IN INDONESIA
}

\author{
Nikmatul Khoiriyah ${ }^{1 *}$, Ratya Anindita ${ }^{2}$, Nuhfil Hanani², Abdul Wahib Muhaimin ${ }^{2}$ \\ ${ }^{1}$ Deparment of Agribusiness, Faculty of Agriculture, University of Islam Malang, Indonesia \\ ${ }^{2}$ Deparment of Socio Economic, Faculty of Agriculture, Brawijaya University, Indonesia
}

*corresponding author: nikmatul@unisma.ac.id

\begin{abstract}
Protein deficiency is one of the causes of the poor nutritional status of the Indonesian population, is permanent, and long-term will have an impact on the lower quality of human resources. This study analyzes the impact of price and income changes on animal food consumption patterns and demand on five poverty level in Indonesia. The demand esimation uses Quadratic Almost Ideal Demand Systems, using the National Socio Economic Survey (SUSENAS) data (March 2016) compilation data of 291,414 households. The results showed that there were different interactions between beef and the other four animal protein food sources, namely the Poor, Almost Poor and Vulnerable Poor beef substitution was mainly chicken, followed by fresh fish and eggs. Hicksian's own-price elasticity decreases following the decrease in the level of household poverty. Cases of beef, household own-price elasticity "extremely poor" $-11.70 \%$ and "not poor" $-1.95 \%$. The sensitivity of the decrease in beef consumption is due to an increase in own-prices for "extremely poor" households 5.5 times compared to "nonpoor". Beef is a very luxurious and relatively inaccessible source of animal protein food, especially for extremely poor, poor, almost poor, and vulnerable poor households, and this constitutes $40 \%$ of Indonesia's population. To increase beef consumption, it is necessary to increase domestic beef production so that the price of beef is affordable not only for non-poor households but also for extremely poor, poor, almost poor and vulnerable poor households in Indonesia
\end{abstract}

Keywords: food demand system, protein, poor household, poverty

http://dx.doi.org/10.21776/ub.agrise.2020.020.1.9

Received 21 November 2019

Accepted 30 December 2019

Available online 31 January 2020

\section{INTRODUCTION}

The development of animal protein consumption can be used as a reference to see the quality of protein consumed by the Indonesian population and can be used as a support for research on nutrition. Protein deficiency is one of the causes of the poor nutritional status of the Indonesian population, which in the long run, will have an impact on the lower quality of human resources. According to Kurnia Dewi (2012), lack of protein consumption and dietary changes are one of the causes of malnutrition in Indonesia. This lack of protein consumption is mainly due to the low economic level of Indonesia's population. The low level of the economy causes their lack of access to quality protein because quality sources of animal protein have a relatively higher price compared to sources of vegetable protein.

The behavior of households to consume an item, including food sources of animal protein, can be influenced by many things including the price of goods, household income, and household preferences for the goods to be consumed.

Differences in preferences of each household due to differences in characteristics such as differences in the location of the region, the level of education of family members, the number of household members, habits, culture, and so on. Thus, changes in food prices, especially food sources of animal protein, and differences in household income will be responded to by 
households differently according to each household's characteristics. Research conducted by Wahyuni, Purnastuti, \& Mustofa (2016) shows that partially the prices of the three food sources of protein (fish, meat, and chicken meat), household expenditure, the area of residence of the household, and the number of household members have an influence on the share of consumption expenditures of the three food sources of protein (fish, meat), and chicken).

Several studies on consumption patterns and demand systems for animal protein source foods have been carried out by several previous researchers, including in Saudi Arabia (Al-Shuaibi, 2011), in Kenya (Bett, Musyoka, Peters, \& Bokelmann, 2012), in Nigeria (Elijah Obayelu, Okoruwa, \& Ajani, 2009), in Swizterland (Abdulai, 2002), (Korir, Rizov, \& Ruto, 2018), and also in Indonesia by Pangaribowo (2010). This research using the Quadratic Almost Ideal Demand Systems (QUAIDS) approach. Generally, in Indonesia, studies of household food demand using the QUAIDS approach are at province level and its analysis divided based on settlement type, urban and rural regions only. The additional five level poverty as unit of analysis would explore deeper insight how the household consumption patterns, and behavior are affected price changes as well as by their poverty level. Therefore the study aims to analyze the impact of price and income changes on animal consumption and food demand patterns at five poverty levels in Indonesia. The results of data analysis will obtain price and income elasticity. The results of the study are expected to be valuable information in compiling a policy scenario of protein fulfillment according to the national protein adequacy rate more effectively, efficiently, and more precisely.

\section{RESEARCH METHODS}

\section{Model specification: Quadratic Almost Ideal Demand System (QUAIDS)}

The QUAIDS model being consistent with demand theory assumptions, it can also allow for non-linear Engel relationships between food group expenditure shares and food expenditure (Banks, Blundell, \& Lewbel, 1997). Ignoring such nonlinear relationships could cause parameter estimates to be inconsistent (Banks et al. 1997). The QUAIDS model will be appropriate when the joint significance of the parameter capturing the quadratic term of income on food group share, for all the food group equations is significantly different from zero.

Following Deaton \& Muellbauer (1980), food and non-food expenditures are assumed to be weakly separable. The QUAIDS, developed by Banks, Blundell, \& Lewbel (1997), which was further augmented with demographic variables by Poi (2013), is used to estimate price and food expenditure elasticities in the second stage. QUAIDS has been widely applied in the literature on food demand analysis. Using the QUAIDS augmented with demographic and other controls to examine the household food demand patterns, and thus availability and access to food, across income groups and types of region.

\section{Demand Estimation}

The approach of estimating QUAIDS for Indonesia, using the SUSENAS 2016 household expenditure survey. On the basis of selected commodity groups, which are indexed by $i$, we estimate a system of demand equations, consisting of total of animal protein consumption expenditure $m$, expenditure shares $\boldsymbol{w}_{i}$ and commodity prices $\boldsymbol{p}_{i}$. The income and price elasticities estimation using settlement type and quintile total expenditure per capita as unit of analysis. The estimation of our system of demand equations following Poi (2012), using non-linear, seemingly unrelated regression.

The QUAIDS model is an AIDS model development. AIDS was discovered by (Deaton, 1980) built on the Rotterdam and Translog models. QUAIDS was developed by (Banks, Blundell \& Lewbel, 1997). Based on the non-parametric analysis of consumer spending patterns, it appears that the Engel curve requires a higher order of logarithm expenditure. The QUAIDS model has almost the same features as AIDS and can capture the curvature of Engel. Therefore, QUAIDS has been chosen as the demand model for estimated empirical strategies. As with the general demand system model, the AIDS model is determined by the following food budget shares (wi):

$$
w_{i} \equiv \frac{p_{i} q_{i}}{m}
$$

where $p_{i}$ is price of $\mathrm{i}, q_{i}$ is quantity of $\mathrm{i}$, and $\mathrm{m}$ is total expenditure, so demand system:

$$
w_{i}=\alpha_{i}+\sum_{j=1}^{k} \gamma_{i j} i n p_{j}+\beta_{i} 1 n\left[\frac{m}{a(p)}\right]
$$

where $p_{j}$ is price of $\mathrm{j}$ and a $(\mathrm{p})$ is index price of total expenditure: 


$$
\begin{aligned}
& \ln \alpha(p) \equiv \alpha_{0}+\sum_{i=1}^{k} \alpha_{i} 1 n p_{i}+ \\
& \frac{1}{2} \sum_{i=1}^{k} \sum_{j=1}^{k} \gamma_{i j} 1 n p_{i} 1 n p_{j}
\end{aligned}
$$

As well as the AIDS Model, the QUAIDS model also needs restrictions to be consistent with utility maximization, i.e.:

$$
\begin{aligned}
\text { Adding up: } \sum_{i=1}^{k} \alpha_{1} & =1 \quad \sum_{i=1}^{k} \beta_{i}=0 \\
\sum_{i=1}^{k} \gamma_{i j} & =0 \quad \forall j
\end{aligned}
$$

Homogeneity: $\sum_{j=1}^{k} \gamma_{i j}=0 \forall j$, and

Slutsky's symmetry: $\gamma_{i j}=\gamma_{j i}$

Restriction on demand theory (4), (5) and (6) are imposed during estimation and ensure that notation (3) defines $\alpha$ (p) as a linearly homogeneus function af the individual prices. Futher, where notation (4), (5) and (6) hold, notation (2) provides a system of demand function which add up to total expenditure $\left(\sum w_{i}=1\right)$, is homogen as long as prices and income are zero according to the Slutsky Symmetry theory (Deaton \& Meullbauer, 1980). So, that the AIDS model can interpreted: as price $\left(p_{j}\right)$ and real expenditure $\left(\frac{m}{\alpha(p)}\right)$ is not change, so share of expenditure $\left(w_{i}\right)$ is constant $\left(\alpha_{i}\right)$.

A development of the AIDS model, the QUAIDS model was proposed by Banks et. al (1997), namely by adding an element of quadratic logarithm of expenditure. This follows the nature of flexibility the Engel curve share of household expenditure is not linear, and some commodities are staple goods and some commodities are luxury goods (Banks et al, 1997). The QUAIDS model in budget share is:

$$
\begin{aligned}
& w_{i}=\alpha_{i}+\sum_{j=1}^{K} \gamma_{i j} 1 n p_{j}+ \\
& \beta_{i} 1 n\left[\frac{m}{\alpha(p)}\right]+\frac{\lambda_{i}}{b(p)}\left\{1 n\left[\frac{m}{\alpha(p)}\right]\right\}^{2}
\end{aligned}
$$

The term equals equation (2) and $b(p)$ is the Cobb-Douglas aggregate price, written as follows:

$$
b(p)=\prod_{j=1}^{K} \rho_{j}^{\beta_{i}}
$$

In the consumer demand theory, adding-up conditions are also needed:

$\sum_{j=1}^{K} \lambda_{j}=0$

When entering the household sociodemographic variable, use the Roy method (1983) based on the expenditure function (cost) as follows: $e(p, z, u)=m_{o}(p, z, u) \times e^{R}(p, u)$

Where $\mathrm{z}$ is a vector of household characteristics, $e^{R}(p, u)$ is expenditure function, and $m_{0}(p, z, u)$ scale of the expenditure function that can be obtained from:

$\overline{m_{o}}(p, z, u)=\overline{m_{o}(z) \phi(p, z, u)}$

where $m_{0}$ measure the increase in household expenditure as a function of $\mathrm{z}$, and $\phi$ is a change in the price of goods consumed. So, $\overline{m_{o}}(z)$ is:

$\overline{m_{o}}(z)=1+\rho z$

where $\rho$ is a vector estimate parameters, $\emptyset(p, z, u)$ is a parameter of:

$\ln \phi(p, z, u)=\frac{\prod_{j=1}^{K} \rho_{j}^{\beta_{i}}\left(\prod_{j=1}^{K} \rho_{j}^{n_{i z}}-1\right)}{\frac{1}{u}-\sum_{j=1}^{K} \lambda_{j} 1 n p_{j}}$

Where $\eta_{j}$ describes the column to j of the matrix parameter $\eta$. To adhere to consumer demand theory, a further adding-up condition is required, given as

$\sum_{j=1}^{K} \lambda_{j} 1 n p_{j}+\left(\beta_{i}+\eta_{i} z\right) 1 n$

for $r=1 \ldots, s$. The estimation of the QUAIDS animal food model can be written into the formula:

$w_{i}=\alpha_{i}+\sum_{j=1}^{K} \lambda_{j} 1 n p_{j}+\left[\frac{m}{\alpha(p 0) \overline{m_{0}}(z)}\right]+$
$\frac{\lambda_{i}}{b(p) c(p, z)}\left\{1 n\left[\frac{m}{\alpha(p 0) \overline{m_{0}}(z)}\right]\right\}^{2}+\varepsilon$

where

$c(p, z)=\prod_{j=1}^{K} \rho_{j}^{n_{i z}}$

The parameters generated from the QUAIDS model are used to calculate the own-price elasticity of both Hicksian and Marshallian, expenditure elasticity and cross price elasticity. Marshallian price elasticity (Uncompensated) is:

$\epsilon_{i j}^{u}=-\delta_{i j}+\frac{1}{w_{i}}\left(\gamma_{i j}-\left[\beta_{i}+\eta_{i}^{\prime} z+\right.\right.$

$\left.\frac{2 \lambda_{i}}{b(p) c(p, z)} 1 n\left\{\frac{m}{\alpha(p 0) \overline{m_{0}}(z)}\right\}\right] \times\left(\alpha_{j}+\sum_{1} \gamma_{j 1} 1 n p_{1}\right)-$

$\left.\frac{\left(\beta_{i}+\eta_{j} z\right) \lambda_{i}}{b(p) c(p, z)}\left[1 n\left\{\frac{m}{\alpha(p 0) \overline{m_{0}}(z)}\right\}\right]^{2}\right)$

Income elasticity is:

$\mu_{i}=1+\frac{1}{w_{i}}\left[\beta_{i}+\eta_{i}^{\prime} z+\frac{2 \lambda_{i}}{b(p) c(p, z)} 1 n\left\{\frac{m}{\alpha(p) \overline{m_{0}}(z)}\right\}\right]$

Hicksian elasticity (Compensated) is: 
$\epsilon_{i j}^{c}=\epsilon_{i j}^{u}+w_{j} \mu_{i}$

Equation (1) to (6) adopted from Deaton and Muellbauer (1980), equation (7) to (19) adopted from (Poi, 2012) with reference to Banks et al. (1997).

\section{Data}

The data used in this research is secondary data of the National Socio-economic Survey (SUSENAS) data (March 2016). The data analyzed were sociodemographic data (household residence status, total household member, household consumption and expenditure, and total expenditure). The animal foods observed in this study were eggs (chicken eggs, local chicken eggs, and duck eggs), chicken meat (local chicken meat and chicken meat), beef, fresh fish (fresh fish and shrimp including fish, shrim, squid, and shellfish) as well as powdered milk (milk powder and infant milk). The sample of this research is 291,414 households.

\section{RESULTS AND DISCUSSION \\ Households' responsiveness to price and income changes}

The results of the QUAIDS analysis show that prices, income, income square, and sociodemographic, namely the number of household members are almost all significant at alpha $1 \%$ to $5 \%$ (Table 1). The income squared is very significant at alpha $1 \%$. This means that the increase in the square of income is very influential on demand for animal food (Korir et al., 2018), (Mittal, 2010). The QUAIDS coefficient also shows whether animal products is a normal item tend to be luxurious or luxury goods tend to be normal (Pangaribowo, 2010), (Mittal, 2010) . Eggs are luxury goods tend to be normal, indicated by a positive sign on the income variable and the quadratic variable of income. Whereas chicken, beef, fish, and milk are normal items, tend to be luxurious, indicated by the sign that the parameter coefficient is negative. Variable demography is also very significant for the demand for animal foods in Indonesia (L. Bopape \& Myers, 2007), (Bellemare, Barrett, \& Just, 2013), (Agbola, 2003).

Table 1. QUAIDS Parameter estimates of animal food demand

\begin{tabular}{|c|c|c|c|c|c|}
\hline $\begin{array}{c}\text { Parameter (Coeff. } \\
\text { and SEM) }\end{array}$ & Eggs (1) & $\begin{array}{c}\text { Chicken meat } \\
\text { (2) }\end{array}$ & Beef (3) & Fresh fish (4) & $\begin{array}{l}\text { Powdered milk } \\
\text { (5) }\end{array}$ \\
\hline Constant & $-0.0699 *$ & $0.6313^{*}$ & $0.1946^{* *}$ & $0.1259 * *$ & $0.1179^{* *}$ \\
\hline$\alpha$ & (0.84986) & $(0.67323)$ & $(0.036894)$ & (0.022589) & (0.040134) \\
\hline Income & $0.2476^{*}$ & $-0.0547 * *$ & $-0.0298 * * *$ & $-0.0052 * * *$ & $-0.1579 * * *$ \\
\hline$\beta$ & $(0.064152)$ & $(0.046363)$ & $(0.012681)$ & $(0.006465)$ & $(0.015136)$ \\
\hline Price & $0.2255^{* *}$ & $-0.1841 * *$ & $-0.0102 * * *$ & $0.0239 * * *$ & -0.055023 \\
\hline$\gamma_{-} 1$ & $(0.044770)$ & $(0.036690)$ & $(0.012160)$ & $(0.007052)$ & $(0.011639)$ \\
\hline$\gamma 2$ & $\begin{array}{l}-0.1841 * * \\
(0.036690)\end{array}$ & $\begin{array}{c}0.1267 * * \\
(0.033924)\end{array}$ & $\begin{array}{l}0.0048 * * * \\
(0.011402)\end{array}$ & $\begin{array}{l}0,0069 * * * \\
(0.006590)\end{array}$ & $\begin{array}{c}0.045605 \\
(0.011356)\end{array}$ \\
\hline & $-0.0102 * * *$ & $0.0048 * * *$ & $-0.0272 * * *$ & $-0.0092 * * *$ & 0.041719 \\
\hline$\gamma_{3} 3$ & $(0.012160)$ & $(0.011402)$ & $(0.013498)$ & $(0,005685)$ & $(0.008408)$ \\
\hline & $0.0239 * * *$ & $0.0069 * * *$ & $-0.0092 * * *$ & $-0.0151 * * *$ & 0,005119 \\
\hline$\gamma \_4$ & $(0.007052)$ & $(0.006590)$ & $(0.005685)$ & $(-0.006603)$ & $(0.005501)$ \\
\hline & $-0.0550 * * *$ & $0.0456 * * *$ & $0.0417 * * *$ & $0.0051 * * *$ & -0.025698 \\
\hline$\gamma_{-} 5$ & (0.011639) & $(0.011356)$ & $(0.008408)$ & $(0.005501)$ & $(0.013065)$ \\
\hline $\begin{array}{l}\text { Income- } \\
\text { squared }\end{array}$ & $\begin{array}{l}0.0129 * * * \\
(0.000735)\end{array}$ & $\begin{array}{l}-0.0034 * * * \\
(0.001092)\end{array}$ & $\begin{array}{l}-0.0016^{* * * *} \\
(0.000463)\end{array}$ & $\begin{array}{l}-0.0003 * * * \\
(0.000330)\end{array}$ & $\begin{array}{l}-0.0077 * * * \\
(0.000684)\end{array}$ \\
\hline$\lambda$ & & & & & \\
\hline $\begin{array}{c}\text { Demography } \\
\eta \_ \text {hhm_tot }\end{array}$ & $\begin{array}{l}-0.0020 * * * \\
(0.000612)\end{array}$ & $\begin{array}{l}0.0018 * * * \\
(0.000393)\end{array}$ & $\begin{array}{l}0.0004 * * * \\
(0.000197)\end{array}$ & $\begin{array}{c}0.00001 * * * \\
(0.000136)\end{array}$ & $\begin{array}{l}-0.0002 * * * \\
(0.000366)\end{array}$ \\
\hline Demography & $\begin{array}{l}0.00006 * * * \\
(0.000032)\end{array}$ & $\begin{array}{l}0.00006 * * * \\
(0.000032)\end{array}$ & $\begin{array}{l}0.00006 * * * \\
(0.000032)\end{array}$ & $\begin{array}{c}0.00006 * * * \\
(0.000032)\end{array}$ & $\begin{array}{l}0.00006 * * * \\
(0.000032)\end{array}$ \\
\hline
\end{tabular}

Source: March 2016 Susenas, STATA analysis, standart errors in parentheses $(* \mathrm{p}<0.1, * * \mathrm{p}<0.05, * * * \mathrm{p}<0.01)$ 


\section{Marshallian own-price elasticity} (uncompensated)

Uncompensated own-price elasticity (Marshallian) for the five animal protein sources of food at five poverty levels is presented in Table 2, while price elasticity is compensated (Hicksian) own-price in Table 3. The results show that all of own-price elasticity, both Marshallian and Hicksian, marked negative and in line with the theory. This is also in line with the research (Alem, 2011),(Alem \& Söderbom, 2010), (Demeke \& Rashid, 2012),
(Valero- Gil \& Valero, 2008). A negative sign on the price elasticity itself means that the demand for the five foodstuffs of animal protein sources derived from eggs, chicken meat, meat (beef), fresh fish, and milk applies to the demand law. This means that an increase in the price of eggs, chicken meat, meat, fresh fish, and milk will cause a decrease in the amount of demand for each of these commodities (Bett et al., 2012), (Burggraf, Kuhn, ZHAO, Teuber, \& Glauben, 2015), (L. E. Bopape, 2006) and (Abramovsky, Attanasio, \& Phillips, 2012).

Table 2. Marshallian own-price elasticity based on poverty level in Indonesia 2016

\begin{tabular}{lccrrr}
\hline Animal food group & \multicolumn{5}{c}{ Demand for animal foods $\downarrow$} \\
\cline { 2 - 6 } & Eggs & $\begin{array}{c}\text { Chicken } \\
\text { meat }\end{array}$ & Beef & Fresh fish & Powdered milk \\
\hline Poverty level & \multicolumn{7}{c}{ Marshallian elasticity (uncompensated) } \\
1.Extremely poor & -0.9200 & -3.1514 & -11.7289 & -2.7674 & -2.2011 \\
2.Poor & -0.9057 & -2.5609 & -9.5588 & -3.0666 & -2.1659 \\
3.Almost poor & -0.8888 & -2.2253 & -7.1867 & -2.8540 & -2.1159 \\
4.Vulnerable poor & -0.8685 & -1.9312 & -5.5549 & -2.7326 & -2.0444 \\
5.Not poor & -0.7480 & -1.3927 & -2.0215 & -2.0284 & -1.6026 \\
\end{tabular}

Based on its own-price elasticity, both Marshallian and Hicksian, only egg commodities have an absolute value below one, which means egg commodities have inelastic properties. This means that when there is an increase in egg prices by $1 \%$, the number of egg demand will decrease by less than $1 \%$. For other commodities, namely chicken meat, beef, fresh fish, and powdered milk, are food sources of animal protein sources that are elastic. This means that the total demand for these four animal protein food source commodities is highly influenced by own-price changes. The results in line with the research of (Aftab, Rehman, Abdul, \& Faheem, 2015), (Katchova \& Chern, 2004), and (Kumar \& Joshi, 2016). The comparison of the two Tables (2 and 3) shows that, in general, all absolute Marshallian ownprice elasticity are always higher than Hicksian own-price elasticity. This indicates that besides being influenced by price changes, animal protein is significantly influenced by household income because of the considerable magnitude of the substitution effect between types of animal food, except eggs.

\section{Hicksian own-price elasticity (compensated)}

The Hicksian own-price elasticity (compensated) for the five food sources of animal protein at five poverty levels is presented in Table 3 . The Hicksian own-elasticity of beef is the most elastic, followed by fresh fish, chicken, and milk powder. The Hicksian own-price elasticity decreases in accordance with the decrease in the level of poverty. It means that the increase in own-prices has a more significant impact on that are not / less prosperous than the more able household. They will reduce consumption significantly if there is an increase in prices. A striking example in the case of beef, the value of the elasticity of the price of the family "extremely poor" $-11.70 \%$ and families "not poor" $1.95 \%$. This means that the sensitivity of the decline in beef spending is due to an increase in own prices for "extremely poor" households 5.5 times compared to "non-poor". 
Table 3. Hicksian own-price elasticity based on poverty levels in Indonesia 2016

\begin{tabular}{|c|c|c|c|c|c|}
\hline \multirow{2}{*}{$\begin{array}{c}\text { Unit Analisys - } \\
\text { Animal food groups }\end{array}$} & \multicolumn{5}{|c|}{ Demand for animal foods $\downarrow$} \\
\hline & Egg & $\begin{array}{r}\text { Chicken } \\
\text { meat }\end{array}$ & Beef & Fresh fish & Milk powder \\
\hline Poverty level & \multicolumn{5}{|c|}{ Hicksian own-price elasticity (compensated) } \\
\hline 1.Extremely poor & -0.4415 & -2.8572 & - & - & -2.0621 \\
\hline & & & 11.7047 & 2.7034 & \\
\hline 2.Poor & -0.4519 & -2.2476 & -9.5304 & -3.0090 & -2.0189 \\
\hline 3.Almost poor & -0.4621 & -1.8960 & -7.1547 & -2.7940 & -1.9640 \\
\hline 4.Vulnerable poor & -0.4790 & -1.5778 & -5.5184 & -2.6715 & -1.8849 \\
\hline 5.Not poor & -0.4997 & -1.0018 & -1.9520 & -1.9477 & -1.3918 \\
\hline
\end{tabular}

Although both are highly elastic, changes in the elasticity of chicken meat's own-price due to changes in poverty status levels are not as drastic as beef. An interesting finding for chicken is that there is a tendency for elastic goods to become inelastic in the non-poor. Own-price elasticity of Hicksian eggs tends to increase from extremely poor to vulnerable poor, then decreases in non-poor. This phenomenon shows the (possibly) shifting patterns of consumption of animal protein sources according to their preferences, especially for households who are well off. The shift from chicken and eggs to beef and possibly also to fresh fish and powdered milk. As indicated by the Hicksian own-price elasticity, the decrease in demand for fresh fish and milk powder is not as large as beef or chicken meat. Little anomaly elasticity of demand for fresh fish occurs in extremely poor; the absolute value of elasticity itself is lower than in poor. However, this trend decreases following the decreasing level of poverty. There is not much research of demand systems on various levels of poverty, but what is often found is urban and rural levels such as research (Ivanic \& Martin, 2014), (Majumder, Ray, \& Sinha, 2012), and (Cudjoe, Breisinger, \& Diao, 2010).

\section{Marshallian cross-price elasticity}

The behavior of consumption of protein-source foods, in addition to being seen from changes in prices, must also consider changes in prices of other food-source protein food commodities. The elasticity of cross-prices represents a change in the percentage of the demand quantity of an item consumed as a result of a $1 \%$ change in the price of other goods.

Analysis based on the poverty level shows that there are different interaction patterns between beef and the other four animal protein food sources. The difference in this interaction is more pronounced, especially in the very poor, which is also found to have a complementary effect with eggs other than milk powder. Because the price of eggs is lower than milk powder, it indicates a shift in complementation due to limited purchasing power (a proxy of total expenditure per capita). This phenomenon needs to be explored further, taking into account other relevant supporting data. For Poor, Almost Poor and Vulnerable Poor substitution of beef is mainly chicken, followed by fresh fish and eggs. For the Non-Poor, the cross-price elasticity with all substituents is less than one, indicating that although there is a substitution effect due to an increase in the price of the meat prices, this substitution effect may not be/less significant.

\section{Hicksian cross-price elasticity}

The cross-price elasticity of both Marshallian and Hickisan is carried out simultaneously on each commodity to see in more detail how the behavior of households in each poor group in consuming animal protein. Tables 4 and 5 are the results of calculations of cross elasticity of animal foods source of protein in five poverty levels in Indonesia.

\section{The cross-price elasticity of eggs}

In the aggregate at the national level, based on Hicksian's ow-price elasticity values, egg demand is inelastic. Based on the status of household poverty shows that the substitution of eggs by powder milk, especially in households that are relatively prosperous in non-poor. There is a tendency for egg substitution by chicken meat to decrease with increasing levels of household welfare. Egg substitution by powdered milk applies. The trend of egg substitution by beef and fresh fish is similar to powdered milk, although the percentage is much smaller. 
Table 4. The cross-price elasticity of Marshallian based on the poverty levels in Indonesia 2016

\begin{tabular}{|c|c|c|c|c|c|}
\hline \multirow{2}{*}{$\begin{array}{l}\text { Unit Analisys - Animal } \\
\text { food groups }\end{array}$} & \multicolumn{5}{|c|}{ Demand for animal foods $\downarrow$} \\
\hline & Egg & Chicken meat & Beef & IFresh fish & $\begin{array}{l}\text { Milk } \\
\text { powder }\end{array}$ \\
\hline 1.Extremely poor & \multicolumn{5}{|c|}{ Marshallian cross-price elasticity (uncompensated) } \\
\hline Egg & -0.9200 & 0.0759 & -5.1455 & -0.1130 & -0.9218 \\
\hline Chicken meat & 0.2361 & -3.1514 & 9.5019 & 0.4838 & 0.7039 \\
\hline Beef & -0.0039 & 0.3031 & -11.7289 & 0.4438 & -0.1867 \\
\hline Fresh milk & 0.0380 & 0.1208 & 3.7655 & -2.7674 & -0.0073 \\
\hline Milk powder & 0.0382 & 0.3419 & -2.8191 & 0.0334 & -2.2011 \\
\hline \multicolumn{6}{|l|}{ 2.Poor } \\
\hline Egg & -0.9057 & -0.0260 & -3.2928 & -0.1703 & -0.7745 \\
\hline Chicken meat & 0.2160 & -2.5609 & 6.8812 & 0.6528 & 0.6579 \\
\hline Beef & 0.0027 & 0.2306 & -9.5588 & 0.5095 & -0.2106 \\
\hline Fresh milk & 0.0357 & 0.1161 & 2.8414 & -3.0666 & -0.0088 \\
\hline Milk powder & 0.0436 & 0.2979 & -2.7444 & 0.0412 & -2.1659 \\
\hline \multicolumn{6}{|l|}{ 3.Almost poor } \\
\hline Egg & -0.8888 & -0.0851 & -2.0686 & -0.1854 & -0.7075 \\
\hline Chicken meat & 0.2001 & -2.2253 & 4.4033 & 0.6534 & 0.5906 \\
\hline Beef & 0.0079 & 0.1792 & -7.1867 & 0.4469 & -0.2007 \\
\hline Fresh milk & 0.0346 & 0.1133 & 2.0172 & -2.8540 & -0.0123 \\
\hline Milk powder & 0.0477 & 0.2549 & -2.0306 & 0.0333 & -2.1159 \\
\hline \multicolumn{6}{|l|}{ 4.Vulnerable poor } \\
\hline Egg & -0.8685 & -0.1269 & -1.2442 & -0.2041 & -0.6162 \\
\hline Chicken meat & 0.1846 & -1.9312 & 2.8212 & 0.6759 & 0.5197 \\
\hline Beef & 0.0142 & 0.1369 & -5.5549 & 0.4085 & -0.1925 \\
\hline Fresh milk & 0.0336 & 0.1074 & 1.4460 & -2.7326 & -0.0145 \\
\hline Milk powder & 0.0532 & 0.2187 & -1.5786 & 0.0293 & -2.0444 \\
\hline \multicolumn{6}{|l|}{ 5.Not poor } \\
\hline Egg & -0.7480 & -0.2515 & -0.1082 & -0.2025 & -0.3423 \\
\hline Chicken meat & 0.1079 & -1.3927 & 0.1677 & 0.5434 & 0.2041 \\
\hline Beef & 0.0419 & 0.0448 & -2.0215 & 0.2245 & -0.0910 \\
\hline Fresh milk & 0.0311 & 0.1105 & 0.3202 & -2.0284 & -0.0156 \\
\hline Milk powder & 0.0751 & 0.1417 & -0.3143 & 0.0166 & -1.6026 \\
\hline
\end{tabular}


Table 5. The cross-price elasticity of Hicksian based on the poverty levels in Indonesia 2019

\begin{tabular}{|c|c|c|c|c|c|}
\hline \multirow{2}{*}{$\begin{array}{l}\text { Poverty level - Animal } \\
\text { food groups }\end{array}$} & \multicolumn{5}{|c|}{ Demand for animal foods $\downarrow$} \\
\hline & Egg & Daging Ayam & Egg & Ikan Segar & Egg \\
\hline 1.Extreamly poor & \multicolumn{5}{|c|}{ Hicksian cross-price elasticity (compensated) } \\
\hline Egg & -0.4415 & 1.8827 & -0.1185 & 1.3885 & 1.1223 \\
\hline Chicken meat & 0.3140 & -2.8572 & 10.3205 & 0.7284 & 1.0368 \\
\hline Beef & -0.0016 & 0.3118 & -11.7047 & 0.4510 & -0.1768 \\
\hline Fresh milk & 0.0584 & 0.1978 & 3.9798 & -2.7034 & 0.0798 \\
\hline Powdered milk & 0.0707 & 0.4648 & -2.4771 & 0.1355 & -2.0621 \\
\hline \multicolumn{6}{|l|}{ 2.Poor } \\
\hline Egg & -0.4519 & 1.4245 & 1.0935 & 1.3483 & 1.0939 \\
\hline Chicken meat & 0.3140 & -2.2476 & 7.8283 & 0.9807 & 1.0613 \\
\hline Beef & 0.0057 & 0.2399 & -9.5304 & 0.5193 & -0.1985 \\
\hline Fresh milk & 0.0529 & 0.1711 & 3.0079 & -3.0090 & 0.0622 \\
\hline Powdered milk & 0.0793 & 0.4120 & -2.3993 & 0.1607 & -2.0189 \\
\hline \multicolumn{6}{|l|}{ 3.Almost poor } \\
\hline Egg & -0.4621 & 1.1720 & 1.4006 & 1.1735 & 1.0364 \\
\hline Chicken meat & 0.3119 & -1.8960 & 5.3121 & 1.0094 & 1.0475 \\
\hline Beef & 0.0118 & 0.1908 & -7.1547 & 0.4594 & -0.1846 \\
\hline Fresh milk & 0.0535 & 0.1688 & 2.1704 & -2.7940 & 0.0647 \\
\hline Powdered milk & 0.0849 & 0.3644 & -1.7284 & 0.1517 & -1.9640 \\
\hline \multicolumn{6}{|l|}{ 4.Extremely poor } \\
\hline Egg & -0.4790 & 0.9388 & 1.5020 & 1.0138 & 0.9524 \\
\hline Chicken meat & 0.3137 & -1.5778 & 3.7319 & 1.0798 & 1.0399 \\
\hline Beef & 0.0193 & 0.1510 & -5.5184 & 0.4246 & -0.1717 \\
\hline Fresh milk & 0.0532 & 0.1609 & 1.5839 & -2.6715 & 0.0642 \\
\hline Powdered milk & 0.0928 & 0.3271 & -1.2994 & 0.1532 & -1.8849 \\
\hline \multicolumn{6}{|l|}{ 5.Not poor } \\
\hline Egg & -0.4997 & 0.4282 & 0.8786 & 0.5271 & 0.5897 \\
\hline Chicken meat & 0.2507 & -1.0018 & 0.7353 & 0.9631 & 0.7402 \\
\hline Beef & 0.0593 & 0.0927 & -1.9520 & 0.2759 & -0.0254 \\
\hline Fresh milk & 0.0585 & 0.1856 & 0.4293 & -1.9477 & 0.0874 \\
\hline Powdered milk & 0.1312 & 0.2954 & -0.0911 & 0.1816 & -1.3918 \\
\hline
\end{tabular}

\section{The cross-price elasticity of chicken meat}

Based on Hicksian's own-price elasticity in the food protein sources of animal protein, "chicken meat" at the national food level is a source of an animal protein whose demand is elastic towards the unitary for urban national aggregates and in "non-poor" household groups. Differences in demand elasticity are higher in rural than in urban areas. Chicken meat elasticity tends to decrease with an increasing level of welfare/household economy (Table 5 and Table 6 ), and demand becomes inelastic in the group of
$40 \%$ of households with the highest level of welfare/economy (not poor). This means that the more prosperous or improved the household economy, the less responsive to price increases. Nationally, the Hicksian cross elasticity shows that there is no complementary effect on the four other animal protein sources if there is an increase in the price of chicken meat. The same results were obtained in the analysis unit of the status of the poverty level "total household expenditure" for the five food sources of animal protein. 


\section{The cross-price elasticity of beef}

Nationally, the absolute value of the elasticity of beef prices decreases with increasing household economic status. This means that the less poor the household, the lower the elasticity. For extremely poor households, the substitution of beef is chicken meat, fresh fish, milk powder, and eggs. Whereas in non-poor households, the substitution of beef is eggs, chicken meat, and fish. In addition to the different substitution order, the proportion of substitution is also different, as indicated by the cross-price elasticity. Powdered milk is complementary to beef in all poverty level.

\section{The cross-price elasticity of fresh fish}

As with other animal protein sources, the sensitivity of the demand to the increase in own-prices according to the increasing level of the economy/household welfare. Despite its sensitivity, the demand for fresh fish is not as big as beef and chicken meat. The main substitution of fresh fish is beef, followed by chicken meat and milk powder. The contribution of eggs as a substitute for meat is relatively small. Perhaps the role of fresh fish is closer to the role of meat, compared to the case for milk powder.

\section{The cross-price elasticity of powdered milk}

Milk powder acts more as a beverage ingredient than an ingredient for food, although in some cases, it can also be used as an ingredient in making food. Sensitivity to the price of milk powder itself decreases with increasing levels of the economy/welfare of the household. The absolute value of own-price elasticity is the smallest compared to chicken, beef, and fresh fish. The complementary level decreases with increasing household economic/welfare. An interesting phenomenon occurs in non-poor households, that beef is no longer complementary to milk powder. The other four sources of animal protein are all substitutive items. This might be interpreted as meaning that the household is not poor; the behavior of consuming animal protein sources is already at the level of diversification, which is more directed at improving nutrition. This is thought to be a consequence of adequate or even excess household income.

\section{Expenditure elasticity}

Expenditures elasticities indicate the response to changes in demand for a commodity due to changes in expenditure/income. The expenditure elasticities of the five groups of protein source food commodities are presented in Table 6. Based on the results of income elasticity calculations, all food commodity sources of animal protein originating from eggs, chicken meat, meat, fish, and milk are positive, which means the food sources are classified as normal goods, not inferior. Based on the elasticity value shows that the elasticity of expenditure of chicken meat, beef, fish, and milk powder is more than 1 (elastic) - luxurious. In contrast, for egg commodities the elasticity value is less than 1 (inelastic) - normal/necessity. This indicates that the commodities of beef, chicken, fish, and milk powder are more responsive to changes in expenditure/income, while egg commodities are not responsive to changes in expenditure/income.

Table 6. Income elasticity based on the poverty levels in Indonesia 2016

\begin{tabular}{lcccrc}
\hline $\begin{array}{c}\text { Unit Analisys } \\
\text { Animal food group }\end{array}$ & Eggs & $\begin{array}{c}\text { Chicken } \\
\text { meat }\end{array}$ & Beef & $\begin{array}{r}\text { Fresh } \\
\text { fish }\end{array}$ & $\begin{array}{c}\text { Powdered } \\
\text { milk }\end{array}$ \\
\cline { 2 - 6 } & \multicolumn{7}{c}{ Income elasticity } \\
\hline Poverty level & 0.6117 & 2.3097 & 6.4261 & 1.9195 & 2.6130 \\
1.Extreamely poor & 0.6076 & 1.9424 & 5.8734 & 2.0334 & 2.5020 \\
2.Poor & 0.5985 & 1.7631 & 4.8653 & 1.9058 & 2.4457 \\
3.Almost poor & 0.5830 & 1.5951 & 4.1105 & 1.8230 & 2.3478 \\
4.Vulnerable poor & 0.4921 & 1.3472 & 1.9561 & 1.4464 & 1.8474 \\
5.Tidak Miskin & & & & & \\
\hline
\end{tabular}

Referring to the value of income elasticity of greater opinion 1 as a luxurious item, beef is the most luxurious food source of animal protein followed by powdered milk, fresh fish, and chicken. In general, the level of "relative luxury" of these four commodities decreases with increasing levels of the economy/household welfare. Chicken meat, fresh fish, and milk powder, although classified as a source of luxury animal protein, but not as luxurious as beef. Beef is the source of animal protein with the widest range of "relative luxuries". This disparity in the level of "relative luxury" becomes wider if an 
analysis of poverty status units is used. This means that beef is a very luxurious and relatively inaccessible source of animal protein, especially for extremely poor, poor, almost poor and vulnerable poor households.

\section{CONCLUSION}

This study explains the impact of changes in prices and incomes on the behavior of consumption and demand for animal-based protein foods, using the QUAIDS approach. The research data used March 2016 SUSENAS data of 291,414 households. The results showed that there were different interactions between beef and the four other animal protein food sources, namely the extremely poor household group, found to have a complementary effect with eggs other than milk powder. Because the price of eggs is cheaper than milk powder, it indicates a shift in complementation due to limited purchasing power (proxy of total expenditure per capita). Poor household, almost Poor and Vulnerable Poor substitution of beef is mainly chicken, followed by fresh fish and eggs. For the Non-Poor, although there is a substitution effect due to an increase in the price of beef itself, the substitution effect is not/less significant.

The own-price elasticity of Hicksian beef is most elastic, followed by fresh fish, chicken meat, and milk powder. The Hicksian own-price elasticity decreases following the decrease in the level of household poverty. The case of beef, the elasticity of the family's own-price "extremely poor" $-11.70 \%$ and families "not poor" $-1.95 \%$. The sensitivity of the decline in beef shopping due to rising prices for "extremely poor" households 5.5 times compared to "non-poor" family groups.

Beef is the most luxurious food source of animal protein followed by powdered milk, fresh fish, and chicken. In general, the level of "relative luxury" of these four commodities decreases with increasing levels of the economy/household welfare. Chicken meat, fresh fish, and powdered milk, although classified as a source of luxury animal protein, are not as fancy as beef. Beef is a very luxurious and relatively inaccessible source of animal protein food, especially for extremely poor, poor, almost poor, and vulnerable poor households, and this constitutes $40 \%$ of Indonesia's population.

Considering that eggs are the most widely consumed animal protein source consumed by households in Indonesia, the government should maintain egg price stability so that protein consumption increases and the national minimum protein adequacy rate is immediately met. To increase beef consumption, it is necessary to increase domestic beef production so that the price of beef is affordable not only for non-poor households but also for extremely poor, poor, almost poor and vulnerable poor households in Indonesia.

\section{Acknowledgement}

Acknowledgments are submitted to the Central Bureau of Statistics of the Republic of Indonesia which has served the data purchasing and to the Ministry of Research, Technology and Higher Education for the funds through the Doctoral Program of Doctoral Dissertation 2018.

\section{REFERENCES}

Abdulai, A. (2002). Household demand for food in Switzerland. A quadratic almost ideal demand system. Revue Suisse D Economie Et De Statistique, 138(1), 1-18.

Abramovsky, L., Attanasio, O., \& Phillips, D. (2012). Demand responses to changes in consumer prices in Mexico: Lessons for policy and an application to the 2010 Mexican tax reforms. Royal Economic Society Conference Paper.

Aftab, M. R., Rehman, M., Abdul, C., \& Faheem, M. (2015). Food Prices and its Impact on Poverty in Pakistan. Pakistan Journal of Social Sciences (PJSS), 35(2).

Agbola, F. W. (2003). Estimation of food demand patterns in South Africa based on a survey of households. Journal of Agricultural and Applied Economics, 35(3), 663-670.

Alem, Y. (2011). The impact of food price inflation on consumer welfare in urban Ethiopia: A quadratic almost ideal demand system approach. Economic Studies Department of Economics School of Business, Economics and Law University of Gothenburg, 54.

Alem, Y., \& Söderbom, M. (2010). Household-level consumption in urban Ethiopia: The impact of food price inflation and idiosyncratic shocks. Department of Economic, University of Gothenbory Sweden. School of Economic, Addis Ababa University of Ethiopia.

Al-Shuaibi, A. M. (2011). An Economic Study of the Demand for Red meat in the Kingdom of 
Saudi Arabia using almost Ideal demand system. Trends in Agricultural Economics, 4(1), 30-40.

Banks, J., Blundell, R., \& Lewbel, A. (1997). Quadratic Engel curves and consumer demand. Review of Economics and Statistics, 79(4), 527539.

Bellemare, M. F., Barrett, C. B., \& Just, D. R. (2013). The welfare impacts of commodity price volatility: Evidence from rural Ethiopia. American Journal of Agricultural Economics, 95(4), 877-899.

Bett, H. K., Musyoka, M. P., Peters, K. J., \& Bokelmann, W. (2012). Demand for meat in the rural and urban areas of Kenya: A focus on the indigenous chicken. Economics Research International, 2012.

Bopape, L. E. (2006). The influence of demand model selection on household welfare estimates: An application to South African food expenditures. Michigan State University. Department of Agricultural Economics.

Bopape, L., \& Myers, R. (2007). Analysis of household demand for food in South Africa: Model selection, expenditure endogeneity, and the influence of socio-demographic effects. African Econometrics Society Annual Conference", Cape Town, South Africa. Citeseer.

Burggraf, C., Kuhn, L., ZHAO, Q., Teuber, R., \& Glauben, T. (2015). Economic growth and nutrition transition: An empirical analysis comparing demand elasticities for foods in China and Russia. Journal of Integrative Agriculture, 14(6), 1008-1022.

Cudjoe, G., Breisinger, C., \& Diao, X. (2010). Local impacts of a global crisis: Food price transmission, consumer welfare and poverty in Ghana. Food Policy, 35(4), 294-302.

Deaton, A. (1980). Muellbauer. J.(1 988 0), Economics and Consumer Behavior, Cam $b$ Ridge U Niversity Press, Cam b Ridge, UK.

Demeke, M., \& Rashid, S. (2012). Welfare impacts of rising food prices in rural Ethiopia: A Quadratic almost ideal demand system approach.

Elijah Obayelu, A., Okoruwa, V. O., \& Ajani, O. I. Y. (2009). Cross-sectional analysis of food demand in the North Central, Nigeria: The quadratic almost ideal demand system (QUAIDS) approach. China Agricultural Economic Review, 1(2), 173-193.
Ivanic, M., \& Martin, W. (2014). Short-and longrun impacts of food price changes on poverty. The World Bank.

Katchova, A. L., \& Chern, W. S. (2004). Comparison of quadratic expenditure system and almost ideal demand system based on empirical data. International Journal of Applied Economics, 1(1), 55-64.

Korir, L., Rizov, M., \& Ruto, E. (2018). Analysis of household food demand and its implications on food security in Kenya: An application of QUAIDS model. 92nd Annual Conference, April 16-18, 2018, Warwick University, Coventry, UK. Agricultural Economics Society.

Kumar, P., \& Joshi, P. K. (2016). Food demand and supply projections to 2030: India. International Trade and Food Security: The Future of Indian Agriculture, 29-63.

Kurnia Dewi, F. (2012). Perbedaan Perkembangan Motorik Halus Antara Balita Stunting dan Non Stunting di Kelurahan Kartasura Kecamatan Kartasura Kabupaten Sukoharjo. Universitas Muhammadiyah Surakarta.

Majumder, A., Ray, R., \& Sinha, K. (2012). Calculating rural-urban food price differentials from unit values in household expenditure surveys: A comparison with existing methods and a new procedure. American Journal of Agricultural Economics, 94(5), 1218-1235.

Mittal, S. (2010). Application of the QUAIDS model to the food sector in India. Journal of Quantitative Economics, 8(1), 42-54.

Pangaribowo, E. H. (2010). Food Demand Analysis of Indonesian Households: Do They Eat Better or SmoNe When They Get Richer. International Conference on Eurasian Economies.

Poi, B. P. (2012). Easy demand-system estimation with quaids. The Stata Journal, 12(3), 433-446.

Valero-Gil, J. N., \& Valero, M. (2008). The effects of rising food prices on poverty in Mexico. Agricultural Economics, 39, 485-496.

Wahyuni, D., Purnastuti, L., \& Mustofa, M. (2016). Analisis Elastisitas Tiga Bahan Pangan Sumber Protein Hewani di Indonesia. Jurnal Economia, 12(1), 43-53. 
This page is intentionally left blank 